\title{
Strengthening School Committee as an Effort to Increase Community Participation
}

\author{
Asmoni \\ STKIP PGRI Sumenep \\ asmoni@stkippgrisumenep.ac.id
}

\author{
Fathurrahman \\ Universitas Islam Lamongan \\ fath@unisla.ac.id
}

\begin{abstract}
Abstrac: This study examines the efforts to increase community participation as an effort to strengthen school committees considering so that the existence of healthy school committees has a significant influence on the presence of superior school services. The approach taken in this study using qualitative methods where data collection through interviews and further documentation carried out induction model analysis by taking the site at Vocational High School 1 Sumenep East Java. The results of the study indicate that school committees of Vocational High School 1 Sumenep strengthen school committees through two activities; first, organizational strengthening of school committees by: 1) executing the establishment of committee members according to democratic rules and principles; 2) Has a Statutes and Bylaws of the organization and the work program of the committee; 3 ) carry out the role and function of the school committee. Secondly, the school committee's education insights are characterized by: 1) school committees are actively involved in the preparation of budget and expenditure plans (RAPBS) 2) the school committee understands the need for quality learning process; and 3) school committees establish partnerships and cooperation synergistically between schools, families and communities.
\end{abstract}

Keywords: strengthening school committees, community participation

\section{INTRODUCTION}

Superior schools require community participation, support, and awareness to enable schools to meet their needs in delivering quality teaching and learning processes and providing services to the community, especially the ability to produce competent graduates. In terms of message [7] that the implementation of education should involve the community to improve the quality of education where community participation in education has been established in the law. The relationship of advanced schooling and community participation has been widely discussed, [10] studies address community participation in relation to social, economic, and cultural identification and local initiation. [13] provides an explanation of the importance of community participation that is highly correlated with the effectiveness of schools. The purpose of developing school and community relationships is proposed [19] to: a) maintain school survival; b) improving the quality of education in the school concerned; c) expedite the learning process; and d) obtain the support and assistance from the community that is needed in the development and implementation of the school program.

Increasing community participation finds momentum along with the paradigm shift of government administration from centralization to decentralization which is marked by the enactment of Law Number 22 Year 1999 on Regional Automomi. Law No. 25 of 2002 on the National Development Program, and particularly Law 20 of 2003 on the National Education System, which is the juridical basis for the implementation of regional autonomy and the regulation of participation, participation and involvement of the community in the development process, . Decentralization in the education management which is the delegation of authority from the central government to units of governmental organizations is intended to bring closer service to the community and enable the emergence of innovation and creativity of school organizers. The role of the community in the implementation of education is accommodated by the government through the implementation of schools with a school-based management model, study of the school-based management model can find out in [17]; [15]; [5]; [8].

The current conditions of school committees generally show some realities, among others: 1) there are still many school committees that are formed instantly, not yet appropriate even some are only appointed by the principal. So the process of formation is generally only to meet the rules of subsidy acceptance; 2) there are some School Committees that have not been able to prepare $\mathrm{AD}$, ART and work programs; 3) in the execution of roles and functions, some school committees have more emphasis on the role of oversight than doing the other three roles (consideration, support and mediation). While school committees of Vocational High School 1 Sumenep have a high commitment in helping schools provide services and improving the quality of education. In this school the school committee has a statute and a household budget committee as well as an organizational work program as a reference for the work of the committee. Committee executives are also involved 'active' in the process of organizing education and teaching. 


\section{METHOD}

The research uses qualitative research design by following [4] that qualitative research has actual setting as direct data source and researcher as key informant. The setting of this study was chosen at Vocational High School in Sumenep Regency East Java which is a favorite school on the island of eastern Madura, namely Vocational High School 1 Sumenep. Sources of data were obtained from school activities and school committees related to the effectiveness of performance and empowerment of school committees on organizational strengthening and performance effectiveness and empowerment of school committees in educational. The data collection of this research is done through interview technique, observation, and documentation. While for data analysis techniques, the researcher refers to the opinion of Miles, Huberman, and Saldana [11] which states that data collection activities are done by classifying, data reduction, displaying data, and making conclusions.

\section{RESULT}

Based on the results of in-depth interviews, observation, documentation, and completed questionnaires on respondents, the performance of school committees of Vocational High School 1 Sumenep can be described in organizational strengthening by schools and school committees: (1) School Committees are democratic; (2) The school committee already has the organization's Articles of Association and By laws and the work program of the organization; and (3) Implement the role and function of School Committees programmatically to improve the quality of education services. At the stage of performance improvement of educational insights school committee characterized by the ability of school committees in understanding the school as a system, school-based management, and implementation of active learning, creative, effective and fun. Results from the field show data that: (1) School committees are actively involved in the preparation of budget plans and school expenditures. (2) School committees understand the need for quality learning processes; and (3) School committees establish partnerships and cooperation synergistically between schools, families and communities.

\section{DISCUSSION}

The conception of school and community relationships explained [19], among others, aims to: a) maintain school survival; b) improving the quality of education in the school concerned; c) expedite the teaching and learning process; d) obtain the support and assistance of the community needed in the development and implementation of school programs.Based on the history, community participation in education begun in the 1950s in schools formed parent and teacher union, the 1970s was changed into auxiliary organizers of education, then through in Government Regulation number 17 of 2010 is school committee. The purpose of the establishment of the School Committee is to: (1) accommodate and channel the aspirations and initiatives of the community in creating operational policies and educational programs in educational units, (2) increasing the responsibility and active participation of all levels of society in the implementation of education in units of Education, (3) transparent, accountable, and democratic conditions in the provision of educational services and education in educational units.

The performance of school committees in organizational strengthening in SMKNegeri 1 Sumenep can be categorized as effective which is indicated by 1) School committees implement the establishment of School Committees in a democratic and obedient manner. Where the school committee set up a committee preparing the election of members of the school committee followed by the establishment of school committees next period including the establishment of school committees referring to the Articles of Association and Bylaws and existing legislation. Furthermore, the existing committee managers prepare the organization's Articles of Association and Bylaws and work program as the guidance of school committees to carry out their roles and functions; (2) The school committee already has the organization's Articles of Association and Bylaws and the work program of the organization; and (3) Implement the role and function of the School Committee programmatically to improve the quality of education services.

The results of Imron's [2] research in MAN Malang 1 found that the management of Madrasah MAN Malang I majors are arranged as follows: (1) the appointment of the board of Madrasah MAN Malang I was passed based on the Decree of Madrasah Head No. MA.m / 12 / PPO1.1 / 304 / SK / 2003, and changed the composition of the board approved by the new Decree of Head of Madrasah No. MA.13.121PP 00/322/2004, (2) the composition of the madrasah board comprises $50 \%$ of parent, community, alumni and 50\% representatives of the teacher council, without involving the students. Similarly, the school committee at Vocational High School 1 Sumenep was established based on Principal Decree number 426.3 / 378 / 101.6.31.13 / 2017 which emphasizes the composition of school committee members recruited from education experts, entrepreneurs, community leaders, and guardians.

Furthermore, it can be seen in [1]; [3]; [9]; that the role that School Committee can run is: 1) advisory agency, advisory to the education unit in formulating, determining and implementing policies, both related to long-term program of school and annual program of school; 2) supporting agency, providing support to the school for the work program that has been established, both in the form of financial support, thinking and personnel in the implementation and education unit of education, (3) controlling agency, control in an effort to realize accountability and transparency in unit unit 
education, and (4) mediators, mediation between units of education, pupils, and other stakeholders.

While the performance stages of educational insights on school committees are characterized by the ability of school committees to understand schools as systems, school-based management, and active, creative, effective and enjoyable learning exercises. Results from the field show data that: (1) School committees are actively involved in the preparation of budget plans and school expenditures. (2) School committees understand the need for quality learning processes; and (3) School committees establish partnerships and cooperation synergistically between schools, families and communities. The school committee has its own budget proposed to the school to meet the needs of the organization, including the involvement of making school expenditure plans and building cooperation with the business world and industry.

It can be stated that the existence of School committees is highly expected to function optimally, especially in (1) encouraging the growth of public attention and commitment to the provision of quality education, (2) cooperating with the community (individual / organization / business / industry) (3) accommodate and analyze the aspirations, ideas, demands, and various educational needs proposed by the community, (4) provide inputs, considerations and recommendations to education units related to education policies and programs, budget and income plans school expenditure, education unit performance criteria; criteria of education personnel; criteria of educational facilities; (5) encouraging parents and communities to participate in education to support quality improvement and equity of education; and (6) conduct evaluation and supervision of education policies, programs, implementation and outputs in educational units.

Related with the results of [16] mentioned that the school committee also build partnership and cooperation relationship in synergy with the business and industry, society, and family to realize the purpose of school. [12] highlighted the lack of roles and functions performed by school committees in providing control to schools, while the role of consideration, support and mediation has been well implemented. Therefore an ideal relationship between school committees and schools needs to be better driven in order to achieve the ideal balance, where each can perform its roles and functions to achieve school progress and provide quality education services. Thus the participation and participation of the community becomes a significant element in the process of organizing an advanced school.

\section{CONCLUSION}

Based on the above discussion, the strengthening of the school committee as an effort to increase the participation of the community undertaken by Vocational High School 1Sumenep is to carry out two activities that lead to increased participation of the community in Education. First, organizational strengthening of school committees, with the following activities: (1) Implementing the principles on which the establishment of the School Committee is democratically established; (2) The school committee already has the organization's Articles of Association and Bylaws and the work program of the organization; and (3) Implement the role and function of the School Committee programmatically to improve the quality of education services. Secondly, the school committee's educational insights are enhanced, with the following efforts: (1) School committees are actively involved in the preparation of budget plans and school expenditures. (2) School committees understand the need for quality learning processes; and (3) School committees establish partnerships and cooperation synergistically between schools, families and communities. The six items proposed by the school committee of Vocational High School 1 Sumenenp are able to contribute significantly to the effort to provide quality education services at Vocational High School 1 Sumenep and make this school committee classified as an effective school committee characterized.

\section{REFERENCES}

[1.] Alip, M \& Soenarto. 2008. Pelaksanaan peran komite sekolah dalam penyelenggaraan SMK di DIY.Jurnal Penelitian dan evaluasi Pendidikan, 1(11), 146 - 162.

[2.] Arifin. I \&Normaningsih, S,D. 2005. Peran Majelis Madrasah dalam Meningkatkan Partisipasi Masyarakat terhadap MAN Malang 1. ManajemenPendidikan, 18(1):65-73.

[3.] Armansyah. 2009. Peranan dan pemberdayaan komite sekolah dalam penyelenggaraan pendidikan SMA Negeri di Kota Binjai. Tesis magister, tidak diterbitkan, Universitas Sumatra Utara. Medan.

[4.] Bogdan, R. C. dan Biklen, S. K. 1998. Qualitative Research for Education: An Introduction to Theory and Methods. New York: Allyn and Bacon, A Viacom Company.

[5.] Darma, Surya 2010. Manajemen Berbasis Sekolah. Jakarta: Direktorat Jenderal Pendidikan Dasar dan Menengah.

[6.] Departemen Pendidikan Nasional. 2003. Dewan Pendidikan dan Komite Sekolah. Jakarta. Depdiknas.

[7.] Depdiknas. 2007. Pemberdayaan dewan dendidikan dan komite sekolah. Jakarta: Direktorat Jenderal Manajeman Pendidikan Dasar dan Menengah

[8.] Dodd, A. Wescott dan Konzal, Jean L. 2000.Making our high schools better, how parents and teachers can work together. New York: St Martin's Griffin.

[9.] Hidayat, Nurdin. 2010. Peran komite sekolah dalam implementasi manajemen pendidikan di SMK N 4 Yogyakarta dan SMK Muhammadiyah 3 Yogyakarta. Tesis magister, tidak diterbitkan, Universitas Negeri Yogyakarta. Yogyakarta. 
[10.] Mahajan, Vandana. 2005. "Janshala in Jharkhand: An Experiment with community involvement in education" International Education Journal. Volume 6 (3), 373-385

[11.] Miles, M. B., Huberman, A. M., \& Saldana, J. 2014. Qualitative data analysis: a methods sourcebook. Sage Publications, Inc.

[12.] Nurlaela, L, et.al. 2011. Strategi peningkatan hubungan kemitraan antara komite sekolah, dunia usaha/dunia industri dengan sekolah menengah kejuruan. Jakarta: Direktorat Jenderal Pendidikan Menengah.

[13.] Panigrahi, Manas Ranjan. 2013. "School Effectiveness at Primary Levels of Education in Relation to Community Participation" International Journal on New Trends in Education and their Implications. Volume 4 (2), 171-18
[14.] Purwanto, Ng. 2009 Administrasi dan Supervisi Pendidikan, Bandung : PT Remaja Rosdakarya.

[15.] Siahaan Amiruddin, Khairuddin, Nasution Irwan. (2006). Manajemen Pendidikan Berbasis Sekolah. Jakarta : Quantum Teaching.

[16.] Supriyanto, A. 2005. Pemberdayaan Komite Sekolah: Wadah Peningkatan Partisipasi Masyarakat dan Pihak Swasta dalam Pendidikan.ManajemenPendidikan, 18(1):2130.

[17.] Zajda, J. 2009. Decentralisation, school-based management, and quality. New York: Springer 
